\title{
Unethical Professional Practices and the Quality of Audit Reports of External Auditors in Selected Audit Firms in Lagos State, Nigeria
}

\author{
Niyi S. Awotomilusi $(\mathrm{PhD})^{*} \quad$ Owonifari, Victor Olufemi \\ Department of Accounting, College of Social and Management Science, Afe Babalola University, Ado Ekiti, \\ Ekiti State, Nigeria
}

\begin{abstract}
The study examined unethical professional practices and the quality of audit reports of external auditors in selected audit firms in Lagos State, Nigeria. This study adopted the descriptive survey research design. The population for this study comprised 500 auditors in Lagos state, Nigeria. The sample of 150 auditors was selected using simple random sampling technique. A well-structured questionnaire was used for data collection, which was validated by experts with a reliability coefficient of 0.79 obtained through Cronbach Alpha method. The administration of the instrument was through physical administration to the respondents in their firms' premises by the researcher with the help of two research assistants, and Google form where the questionnaire was pasted on the auditors' platform on whatsapp and telegram for the respondents to fill. Data collected were analysed using descriptive statistics of frequency counts, percentage, mean and standard deviation for the research questions, and inferential statistics of regression analysis for testing the hypothesis at 0.05 level of significance. The study revealed that poor audit planning and auditors' lack of integrity have significant effects on the quality of audit reports of external auditors in Nigeria. In conclusion, poor audit planning of auditors and auditors' lack of integrity are affecting the quality of audit reports in Lagos state Nigeria. The study recommended, among others, that external auditors should always properly plan their audit work so that they would be able to do extensive work that will promote their professionalism and make the audit report to be useful to users of financial information for making investment decisions.
\end{abstract}

Keywords: Quality Audit, Poor Audit Planning, Lack of Integrity, External Auditor.

DOI: $10.7176 / \mathrm{RJFA} / 13-2-10$

Publication date: January $31^{\text {st }} 2022$

\section{Introduction}

The role of audit reports cannot be underestimated especially when it comes to making investment decisions for the future. Various users of audit reports such as employee, creditors, suppliers, public, investors, management and government rely on the opinion of the external auditors for different purposes. The reason why many of these users believed in the opinion of the external auditors is because such reports must have passed through a rigorous examinations by qualified and practicing auditors. Hence, the external auditor is in position to form an opinion on whether account presented and audited shows a true and fair view; this opinion on the audit reporting is the foundation of the decision making for the users. This makes an auditor to be a watchdog for decision making of the stakeholders. According to Akinbuli (2010) audit reporting helps industry and society as a whole to allocate resources more efficiently. Arter (2017) in this regard, described auditors as the "gatekeeper" in safeguarding the public investments. Stakeholders or users trust external auditors because they believe they are professional and neutral. Therefore, their report is considered reliable or trustworthy.

The primary aim of auditing financial records, according to the International Standard on Auditing (2000), is for the auditor to assert an opinion on the prepared financial statements that it has been done based on the identified financial reporting framework (Hayes, Schilder, Dassen \& Wallage, in Ebimobowei \& Bariweni, 2012). Also, Okezie and Egeolu (2019) opined that "in order for users of the financial statement to gain assurance that the financial statement data are being reported and measured properly and also fairly presented, independent certified auditors audit the financial statement and express an opinion on the statements". However, despite all these, some firms are still running into debt, resulting to foldup (Awotomilusi \& Ogunleye, 2021). Recently it was observed that some companies failed despite the fact that the report of the external auditors were favourable. Examples of companies that failed because of the auditing scandal includes; Enron crisis in 2001; Parmalat in 2003; Cadbury Nigeria Plc in 2006; and Afribank Nigeria Plc in 2009. It could be deduced that the failure of these companies was as a result of some unethical professional practices among auditors. That is why the Centre for Audit quality in Fossung and La Fortune (2019) affirmed that "audit quality largely depends on the individuals who conduct the audit".

Many researchers have carried out studies to ascertain which unethical professional practices could affect the quality of the audit reports. Akenbor and Tennyson (2014) affirmed that the causes of unethical behavior in Nigeria includes greediness and selfish interest, pressures from employers and clients, poor societal value, and inadequate 
information. Also, Omorokpe, and Nomuoja (2019) revealed that some of the practicing unethical behaviour among auditors, are requesting funds for equities and/or top executives in the client organization, failing to adhere to relevant auditing standards while conducting an audit, greed on the part of the auditor and the auditor's quest to retain his appointment or tenure with the client, and, outcome of conflicts of interest.

Empirically, different studies have been carried out to investigate unethical practices of the auditors. Fossung and La Fortune (2019) examined the contributions of external audit in improving the quality of accounting and financial information generated by unlisted Cameroon companies. The sample of the study was 52 employees in the selected firm in Cameroon. Analysis of variance and regression were used to test the hypothesis of the study. The findings show that auditor's field of specialization does not reduce accounting and financial information manipulation, the duration of the auditor's mandate and the auditor's reputation both had a significant effect on the quality of financial information.

Similarly, the effect of managerial ownership, audit quality, and audit committee on earnings management was investigated by Sitanggang, Ikhsan, and Nasirwan (2020). Manufacturing companies listed in Indonesia Stock Exchange between 2014 to 2018 were the focus of the study. Multiple regression analysis was used to test the hypotheses in the study. The findings showed that managerial ownership has no significant impact on earnings management; the quality of the audit has an impact on earnings management; the audit committee has a strong influence on how the company manages its earnings; and finally, the study discovered that managerial ownership, audit quality, and audit committee all had a $25.4 \%$ impact on earnings management.

The effect of audit quality on financial reporting was investigated by Ogungbade, Adekoya and Olugbodi (2020). The financial statement of the eleven selected money banks listed in Nigeria Stock Exchange (NSE) for the period of 2009-2018 were used for the study. The data were analyzed with Hausman's test, fixed and Random effect model, and panel multiple regression. The results of the study showed that audit tenure, firm's size and auditor's fees affect the quality of financial reporting, however, the auditor's fees was only significant among the independent variables.

Similar study was conducted by Hasan, Kassim \& Hamid (2021) to investigates the ethical rules of auditing and the impact of compliance with the ethical rules on auditing quality. The sample of the study was 59 practicing auditors. Regression and t-test analysis were used to analyze the data collected for the study. Results of the study showed that degree of commitment to the professional ethics by the auditors has impact on the audit quality.

A study conducted by Ezuwore-Obodokwe and Agbo (2020) examined the relationship between auditor's independence and the credibility of audited financial statements in Nigeria. The study adopted a survey research design. Questionnaire was used to collect relevant data from 150 users of audited financial statement in Enugu state. Chi-square was used to test the hypotheses formulated for the study. Findings of the study revealed that there was a significant relationship between the external auditor's integrity, and the credibility of audited financial statements in Nigeria. Also, the study revealed that objective approach to the audit process is significantly connected with the credibility of audited financial statements in Nigeria.

From the above, it could be deduced that for external auditors to produce quality audit reports, according to Okezie and Egeolu (2019), "the audit firm and the auditor must not be compromised and they must not compromise quality to achieve financial or non-financial benefits". The lack of trust in financial reporting and auditing caused by business failures and audit failures in a number of nations, including Nigeria, is the drive for audit independence and quality control reforms. The results of this have led to strict regulation in an attempt to regain public and investors' confidence in audit reporting. It is against this background that this study examined unethical professional practices and the quality of audit reports of external auditors in selected audit firms in Lagos State, Nigeria.

\section{Purpose of the Study}

The purpose of this study was to examine the effects of unethical professional practices on the quality of the report of external auditors of selected audit firms in Lagos state, Nigeria. Specifically, the study:

i. examined the effects of poor audit planning on the quality of external audit reporting of selected audit firms in Lagos state, Nigeria.

ii. investigated the effects of auditors' lack of integrity on the quality of external audit reporting of selected audit firms in Lagos state, Nigeria.

\section{Research Questions}

Two research questions were raised to guide the study.

i. What are the effects of poor audit planning on the quality of the reports of external auditors in Lagos state, Nigeria?

ii. What are the effects of auditors' lack of integrity on the quality of the reports of external auditors in Lagos state, Nigeria? 


\section{Research Hypothesis}

One research hypothesis was formulated in the study.

H01: There is no significant effect of poor audit planning and auditors' lack of integrity on the quality of audit reports of external auditors of audit firms in Nigeria.

\section{Methodology}

This study adopted the descriptive survey research design. The population for this study comprised 500 auditors in Lagos state, Nigeria. A sample of 150 auditors was selected using a simple random sampling technique. A wellstructured questionnaire was used for data collection. The instrument was validated by experts and the reliability of the instrument was ensured. The reliability coefficient of 0.79 was obtained through Cronbach Apha method. The administration of the instrument took two forms; physical administration to the respondents in their firms' premises by the researcher and with the help of two research assistants. Also, Google form was used, the questionnaire was pasted to the auditors' platform on whatsapp and telegram for the respondents to fill. Data collected were analysed using descriptive and inferential statistics. The research questions were analysed using mean and standard deviation while the hypothesis was tested using regression analysis at 0.05 level of significance.

\section{Results}

Descriptive Analysis

Research Question 1: What are the effects of poor audit planning on the quality of audit reports of external auditors?

Table 1: Responses on the effects of poor audit planning on the quality of audit reports of external Auditors

\begin{tabular}{|c|c|c|c|c|c|c|c|}
\hline $\mathrm{S} / \mathrm{N}$ & Item & SA & A & $\mathrm{D}$ & SD & Mean & St.D Decisions \\
\hline 1 & $\begin{array}{l}\text { Poor audit planning gives a } \\
\text { fraudulent view about the quality } \\
\text { of audit reporting. }\end{array}$ & $\begin{array}{l}57 \\
(42.2 \%)\end{array}$ & $\begin{array}{l}51 \\
(37.8 \%)\end{array}$ & $\begin{array}{l}20 \\
(14.8 \%)\end{array}$ & $\begin{array}{c}7 \\
(5.2 \%)\end{array}$ & 3.17 & 0.86 Agreed \\
\hline 2 & $\begin{array}{l}\text { Poor audit planning creates wrong } \\
\text { impression to investors about the } \\
\text { quality of audit reporting. }\end{array}$ & $\begin{array}{l}40 \\
(29.6 \%)\end{array}$ & $\begin{array}{l}82 \\
(60.7 \%)\end{array}$ & $\begin{array}{l}11 \\
(8.1 \%)\end{array}$ & $\begin{array}{c}2 \\
(1.5 \%)\end{array}$ & 3.18 & 0.63 Agreed \\
\hline 3 & $\begin{array}{l}\text { Poor audit planning leads to } \\
\text { corporate bankruptcy. }\end{array}$ & $\begin{array}{l}67 \\
(49.6 \%)\end{array}$ & $\begin{array}{l}55 \\
(40.7 \%)\end{array}$ & $9(6.7 \%)$ & $4(3 \%)$ & 3.37 & 0.74 Agreed \\
\hline 4 & $\begin{array}{l}\text { Poor audit planning leads to bias } \\
\text { opinion of the authors on the } \\
\text { financial reporting. }\end{array}$ & $\begin{array}{l}67 \\
(49.6 \%)\end{array}$ & $\begin{array}{l}62 \\
(45.9 \%)\end{array}$ & $5(3.7 \%)$ & $\begin{array}{c}1 \\
(0.7 \%)\end{array}$ & 3.44 & 0.60 Agreed \\
\hline 5 & $\begin{array}{l}\text { Poor audit planning makes } \\
\text { companies look better than they } \\
\text { really are. }\end{array}$ & $\begin{array}{l}49 \\
(36.3 \%)\end{array}$ & $\begin{array}{l}69 \\
(51.1 \%)\end{array}$ & $\begin{array}{l}17 \\
(12.65)\end{array}$ & - & 3.23 & 0.66 Agreed \\
\hline 6 & $\begin{array}{l}\text { Poor audit planning will fall } \\
\text { company market price }\end{array}$ & $\begin{array}{l}74 \\
(54.8 \%)\end{array}$ & $\begin{array}{l}48 \\
(35.6 \%)\end{array}$ & $\begin{array}{l}10 \\
(7.4 \%)\end{array}$ & $\begin{array}{c}3 \\
(2.2 \%)\end{array}$ & 3.42 & 0.72 Agreed \\
\hline 7 & $\begin{array}{l}\text { Poor audit planning will make } \\
\text { shareholders lose } \\
\text { money/investment. }\end{array}$ & $\begin{array}{l}68 \\
(50.4 \%)\end{array}$ & $\begin{array}{l}61 \\
(45.2 \%)\end{array}$ & $6(4.4 \%)$ & - & 3.45 & 0.58 Agreed \\
\hline 8 & $\begin{array}{l}\text { Poor audit planning causes } \\
\text { company's loss of tax to the } \\
\text { government }\end{array}$ & $\begin{array}{l}39 \\
(28.9 \%)\end{array}$ & $\begin{array}{l}91 \\
(67.4 \%)\end{array}$ & $\begin{array}{l}5 \\
(3.7 \%)\end{array}$ & - & 3.25 & 0.51 Agreed \\
\hline & Weighted Mean & & & & & 3.31 & Agreed \\
\hline
\end{tabular}

Mean equal or grater than 2.50 indicate Agree otherwise "Disagree"

Source: Filed Survey 2021

Table 1 showed the results of the effects of poor audit planning on the quality of external audit reporting. The results revealed that majority $(80 \%)$ of the respondents indicated that poor audit planning gives a fraudulent view about the quality of audit reporting; creates wrong impression to investors about the quality of audit reporting $(90.3 \%)$; leads to corporate bankruptcy $(90.3 \%)$; leads to bias opinion of the auditors on the financial reporting (95.5\%); makes companies look better than they really are (87.4\%); falls company market price $(99.6 \%)$; makes shareholders to lose their money/investment (95.6\%); and (93.3\%) revealed that poor audit planning causes company loss of tax to the government. This implies that poor audit planning has effect on the quality of the audit report of external auditors in Nigeria. The mean values of respondents in the table are greater than 2.50. This further confirmed the level of agreement of the respondents on the effects of poor audit planning on the quality of the audit report of external auditors in Nigeria.

Research Question 2: What are the effects of auditors' lack of integrity on the quality of external audit reporting of selected audit firms in Lagos state, Nigeria? 
Table 2: Responses on the effects of auditors' lack of integrity on the quality of audit reports of external auditors

\begin{tabular}{|c|c|c|c|c|c|c|c|c|}
\hline $\mathrm{S} / \mathrm{N}$ & Item & SA & $\mathrm{A}$ & $\mathrm{D}$ & SD & Mean & St.D & Decisions \\
\hline 9 & $\begin{array}{l}\text { Lack of integrity declines the } \\
\text { believe of the client in the } \\
\text { services provided. }\end{array}$ & $\begin{array}{c}74 \\
(54.8 \%)\end{array}$ & $\begin{array}{c}59 \\
(43.7 \%)\end{array}$ & $\begin{array}{c}2 \\
(1.5 \%)\end{array}$ & - & 3.53 & 0.52 & Agreed \\
\hline 10 & $\begin{array}{l}\text { High degree of lack of integrity } \\
\text { reduces public trust in the } \\
\text { external audit reporting. }\end{array}$ & $\begin{array}{c}64 \\
(47.4 \%)\end{array}$ & $\begin{array}{c}44 \\
(32.6 \%)\end{array}$ & $\begin{array}{c}9 \\
(6.7 \%)\end{array}$ & $\begin{array}{c}18 \\
(13.3 \%)\end{array}$ & 3.14 & 1.03 & Agreed \\
\hline 11 & $\begin{array}{l}\text { High auditors' lack of integrity } \\
\text { leads to providing the wrong } \\
\text { opinion in accordance with the } \\
\text { actual situation. }\end{array}$ & $\begin{array}{c}45 \\
(33.3 \%)\end{array}$ & $\begin{array}{c}40 \\
(29.6 \%)\end{array}$ & $\begin{array}{c}32 \\
(23.7 \%)\end{array}$ & $\begin{array}{c}18 \\
(13.3 \%)\end{array}$ & 2.82 & 1.04 & Agreed \\
\hline 12 & $\begin{array}{l}\text { Lack of integrity reduces } \\
\text { confidentiality of the users of } \\
\text { audit reporting. } \\
\text { Weighted Mean }\end{array}$ & $\begin{array}{c}83 \\
(61.5 \%)\end{array}$ & $\begin{array}{c}41 \\
(30.4 \%)\end{array}$ & $\begin{array}{c}11 \\
(8.1 \%)\end{array}$ & - & 3.53 & 0.64 & Agreed \\
\hline
\end{tabular}

Mean equal or grater than 2.50 indicate Agreed otherwise "Disagreed"

Source: Filed Survey 2021

The result presented in Table 2 revealed that majority (98.5\%) of the respondents indicated that auditors' lack of integrity declines the believe of the clients in the services provided; degree of lack of integrity expands public trust in the external audit reporting (80\%); auditors' lack of integrity leads to providing the wrong opinion in accordance with the actual situation $(62.9 \%)$; and, $91.9 \%$ showed that lack of integrity reduced confidentiality of the users of audit reports. The result showed that auditors' lack of integrity affects the quality of external audit reporting. All the mean values are greater than 2.50 which further justified the claim that auditors' lack of integrity affects the quality of the audit report of external auditors in Nigeria.

\section{Test of Hypothesis}

There is no significant effect of poor audit planning and auditors' lack of integrity on the quality of audit reports of external auditors of audit firms in Nigeria.

Table 3: Regression analysis showing significant effects of poor audit planning and auditors' lack of integrity on the quality audit of the report of external auditors in Nigeria.

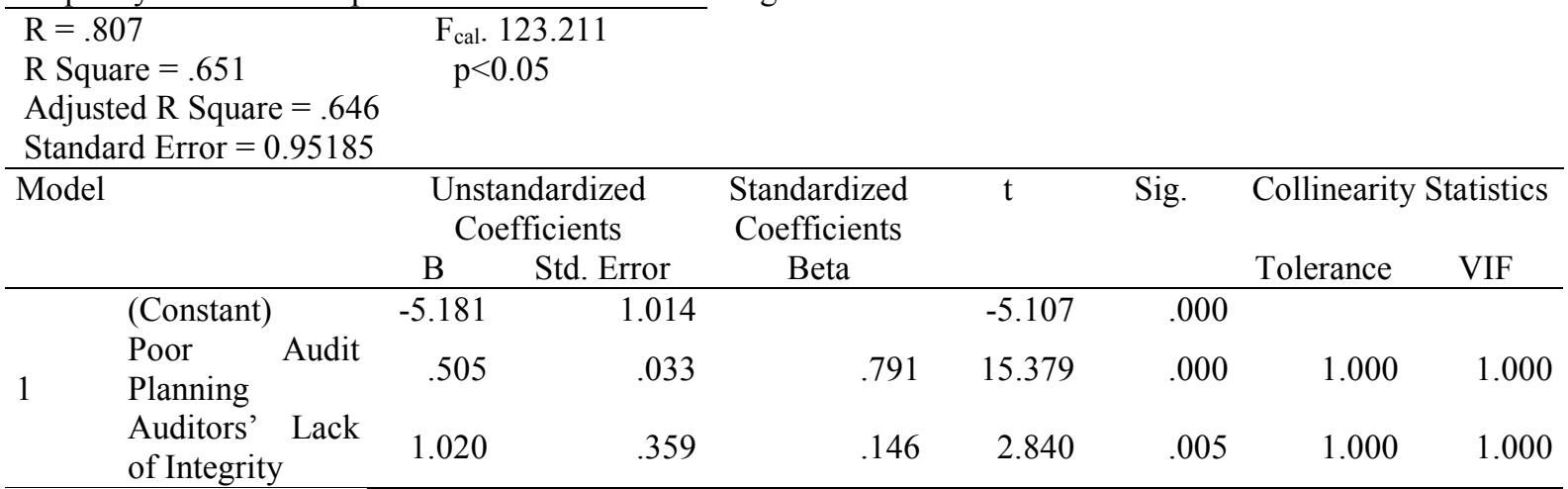

Source: Filed survey 2021

The results of the regression analysis shown in table 3 revealed that there is significant effects of the two independent variables on the quality of the audit report of external auditors at (0.05) level of significance. Thus, the null hypothesis is rejected. The result revealed that poor audit planning and auditors' lack of integrity have significant effects on quality audit reporting $(\mathrm{F}=123.211, \mathrm{P}<0.05)$. The result further revealed that poor audit planning and auditors' lack of integrity explained (65.1\%) of the variance in audit quality of external auditors. The remaining 34.9\% variance in audit reporting could be attributed to other variables outside the regression model. The Beta coefficient of 0.791 indicates that poor audit planning has the most effect on quality audit reporting and Beta coefficient of 0.146 revealed that auditors' lack of integrity has effects on quality audit reporting.

The $\mathrm{t}$-value in the table further confirmed that poor audit planning $(\mathrm{t}=15.379, \mathrm{P}<0.05)$, and auditors' lack of integrity $(\mathrm{t}=2.840, \mathrm{P}<0.05)$ had significant effects on audit quality of auditors at 0.05 level of significance in each case.

The results revealed that an increase in poor audit planning of auditors by (0.505) led to a corresponding decrease of -5.181 in audit quality; also, an increase in auditors' lack of integrity by 1.020 led to a corresponding decrease of -5.181 in audit quality. The implication of this is that, the more auditors fail to plan their audit work, the more the quality of the report of external auditors is affected. Also, if auditors' lack of integrity continues, it 
will affect the quality of the report of external auditors.

\section{Discussion of Findings}

The results revealed that there is significant effect of the two independent variables on the quality of the audit report of external auditors. This means that poor audit planning leads to a fraudulent view about the quality of audit reporting; creates wrong impression to investors about the quality of audit reporting by audit firms; causes companies' loss of tax to the government; and also leads to corporate bankruptcy. The study supports that of Fossung and La Fortune (2019) who found that the auditor's field of specialization did not reduce manipulation of accounting and financial information. The study is also in line with the study of Ezuwore-Obodokwe and Agbo (2020) who revealed that the objective approach to the audit process is significantly connected with the credibility of audited financial statements in Nigeria.

The result revealed that poor audit planning and auditors' lack of integrity have significant effects on the quality of audit. This means that auditors' lack of integrity declines the believe of the clients in the services provided by the external auditors; reduces public trust in the reports of external auditors; it leads to making the wrong opinion in accordance with the actual situation; and reduces the confidence of the users on the quality audit reports of the external auditors. The finding supports the finding of Ezuwore-Obodokwe and Agbo (2020) who revealed that there was a significant relationship between the external auditor's integrity, and the credibility of audited financial statements in Nigeria.

Furthermore, the results revealed that an increase in poor audit planning of auditors led to a corresponding decrease in audit quality. This means that the more auditors fail to plan their audit work, the more the quality of the reports of external auditors is negatively affected. Also, if auditors' lack of integrity continues, it will affect the quality of the report of external auditors negatively.

\section{Conclusion and Recommendations}

The study examined the effects of unethical professional behaviors on the quality of the reports of external auditors in Nigeria. Out of the various unethical professional behavior among auditors, the study basically investigated the effects of poor audit planning and auditors' lack of integrity on the quality of the reports of external auditors. Based on the results of the study, it was concluded that poor audit planning and auditors' lack of integrity have significant effects on the quality of the audit report of external auditors in Nigeria. The implication of this result is that, when poor audit planning and lack of integrity among auditors are on the increase, the more the quality of audit report will be negatively affected. Therefore, the study recommended that external auditors should always properly plan their audit work so that they would be able to do extensive work that will promote their professionalism and make the audit reports to be useful to users of financial information for making investment decisions. Also, some measures should be put in place by regulatory bodies such as ICAN and ANAN to curb lack of integrity among auditors so that they will not tarnish the image of the audit profession in Nigeria.

\section{References}

Akenbor, C. O. \& Tennyson, O. (2014). Ethics of accounting profession in Nigeria. Journal of Business and Economics, 5(8), 1374-1382.

Akinbuli, S. F. (2010.) The effect of audit expectation gap on the work of auditors, the profession and users of financial information. Niger. Accountant, 43(4): 37-47.

Awotomilusi, N. S. \& Ogunleye, W. A. (2021). Whistleblowing policy and fraud prevention and detection of listed deposit money banks: Experience from Ekiti State, Nigeria. International Journal of Accounting, Finance and Risk Management 6(4), 112-120. doi:10.11648/j.ijafrm.20210604.13

Ebimobowei, A. \& Binaebi, B. (2013). An examination of the effectiveness of auditing of local government financial reports in Bayelsa State, Nigeria. Current Research Journal of Social Sciences, 5(2), 45-53.

Ezuwore-Obodokwe, O. \& Agbo, E. I. (2020). Relationship between auditor's independence and the credibility of audited financial statements in Nigeria. Journal of Accounting Information and Innovation, 6(9), 26-37.

Fossung, M. F. \& La Fortune, M. W. S. (2019). External audit and quality of accounting and financial information in Cameroonian companies. European Journal of Accounting, Auditing and Finance Research, 7(3), 55-72.

Hasan, S.; Kassim, A. A. M. \& Hamid, M. A. A. (2020). The impact of audit quality, audit committee and financial reporting quality: Evidence from Malaysia. International Journal of Economics and Financial Issues, 10(5), $272-281$.

Ogungbade, O. I.; Adekoya, A. C \& Olugbodi, D. I. (2020). Audit quality and financial reporting quality of deposit money banks listed on the Nigerian Stock Exchange. Journal of Finance Accounting and Auditing Study 7(1), 77-98.

Okezie, S. O. \& Egeolu, U. D. (2019). Audit independence and reliability of financial reports: Empirical evidence from Nigerian Banks. International Journal of Economics and Business Management 5 (3), 43-52.

Omorokpe, R. O. \& Nomuoja, J. O. (2019). Unethical practices by accountants, auditors, company secretaries and 
directors: Types, causes and remedies. Unpublished Paper.

Sitanggang, S. N.; Ikhsan, A. \& Nasirwan, N. (2020). Analysis of the influence of managerial ownership, audit quality and audit committee on income management (study on manufacturing companies in the consumer goods sector listed on the Indonesia Stock Exchange 2014-2018). Budapest International Research and Critics Institute (BIRCI-Journal): Humanities and Social Sciences, 3(3), 2521-2533. 